\title{
Causes and consequences of change rates in the habitat of the threatened tropical porcupine, Sphiggurus mexicanus (Rodentia: Erethizontidae) in Oaxaca, Mexico: implications for its conservation
}

\author{
Consuelo Lorenzo ${ }^{1 *}$, Eugenia C. Sántiz ${ }^{1}$, Darío A. Navarrete ${ }^{2} \&$ Jorge Bolaños $^{1}$ \\ 1. Departamento de Conservación de la Biodiversidad, El Colegio de la Frontera Sur, Carretera Panamericana y \\ Periférico Sur s/n. C. P. 29290. San Cristóbal de Las Casas, Chiapas, México; clorenzo@ecosur.mx, \\ esantiz@ecosur.edu.mx,jbolanos@ecosur.mx \\ 2. Laboratorio de Información Geográfica, El Colegio de la Frontera Sur, Carretera Panamericana y Periférico Sur s/n. \\ C. P. 29290. San Cristóbal de Las Casas, Chiapas, México; dnavarrete@ecosur.mx \\ * Correspondence
}

Received 25-II-2014. Corrected 10-VII-2014. Accepted 13-VIII-2014.

\begin{abstract}
Land use changes by human activities have been the main causes of habitats and wildlife population degradation. In the Tehuantepec Isthmus in Oaxaca, the tropical habitat of the porcupine Sphiggurus mexicanus has been subject to vegetation and land use changes, causing its reduction and fragmentation. In this study, we estimated vegetation cover and land use $\left(\delta_{n}\right)$ change rates and assessed habitat availability and potential corridors for possible porcupine movements to avoid its isolation. In the study area, the type of vegetation with the most change rate value was the savanna $\left(\delta_{n}=-2.9\right)$, transformed into induced grasslands. Additionally, we have observed the porcupine (since 2011) in semi-deciduous $\left(\delta_{n}=-0.87\right)$ and tropical dry $\left(\delta_{n}=-0.89\right)$ forests that have been transformed in temporal agriculture and mesquite and induced grasslands. The vegetation inhabited by the porcupine resulted in recording a total of 64 plant species (44 trees, nine vines, seven herbs, four shrubs), of which the vine Bunchosia lanceolata showed the highest importance value (41.85) followed by the trees Guazuma ulmifolia (22.71), Dalbergia glabra (18.05), and Enterolobium cyclocarpum (17.02). The habitat evaluation and potential corridor analysis showed that only 1501.93 ha could be considered as suitable habitats with optimum structural conditions (coverage, surface, and distances to transformed areas) to maintain viable populations of S. mexicanus, and 293.6ha as corridors. An increasing destruction of the porcupines' habitat has been observed in the study area due to excessive logging, and actions for this species and its habitat conservation and management have to be taken urgently. Rev. Biol. Trop. 62 (4): 1481-1494. Epub 2014 December 01.
\end{abstract}

Key words: Sphiggurus mexicanus, corridors, habitat availability, selection, Tehuantepec Isthmus, tropical porcupines, use, plant associations.

The tropical forest ecosystems are strategically important areas because of the great species diversity they harbor, and the environmental services they offer (soil stabilization and potential for carbon capture, water cycle, and climate regulation). Unfortunately, they are the most deforested; it has been documented that $650000 \mathrm{ha}$ of tropical forest in Mexico are lost each year, and about 2\% have been lost annually since the beginning of the eighties (Galicia et al., 2007). Mexico has $104023 \mathrm{~km}^{2}$ of tropical forests, and the
Tehuantepec Isthmus in the State of Oaxaca has approximately $12163.5 \mathrm{~km}^{2}$ of tropical forests (INEGI, 2012), which is historically a region of anthropogenic use (Gómez-Martínez, 2005). The main causes of destruction of vast areas of forests and arid zones in the Tehuantepec Isthmus are due to changes in land use because of agricultural activities and forest fires (González et al., 2004; INEGI, 2005).

Despite the ecological and economic importance of forest ecosystems, a monitoring system of land use changes, its causes, 
explanations, and predictions is not available (Galicia et al., 2007). It is essential to carry out studies of the causes, consequences, and spatial and temporal variation of deforestation, change rates of land use in the country and to identify the possible vegetation corridors that can be used for movements of the individuals of different species to avoid their isolation. All these aspects will allow us better planning efforts to conserve, restore, and manage the diverse and abundant forest resources in Mexico.

Changes in distribution, land use surface, and vegetation cover bring degradation, reduction, and fragmentation of wildlife habitats as a consequence in accelerated rates. This situation has caused the presence of small and isolated populations of a great number of mammal species since about $30 \%$ of them are threatened or endangered, and at least 13 species have disappeared from the national territory in the last century (Ceballos et al., 2002). Therefore, the connections (corridors) between habitats play a fundamental role in ecological dynamics, avoiding the isolation of organisms in fragmented landscapes that allow their displacement (Ochoa, 1993; Sorrell, 1997), promoting genetic exchange and supporting ecological processes (Puth, \& Wilson, 2001).

One of these threatened species in Mexico is the tropical porcupine Sphiggurus mexicanus that occurs in the Isthmus, a highly modified ecosystem mainly due to human activities (SEMARNAT, 2010). This taxon is considered as least concern in the red list of the International Union for Conservation of Nature (IUCN, 2012) and one of the least studied mammals, partly because it is solitary, territorial, strictly nocturnal, and has arboreal behavior (Aranda, 2000; Monterrubio-Rico et al., 2010). The species eats seeds, fruits, leaves, flowers, and buds (Janzen, 1983; Emmons \& Feer, 1997; Wainwright, 2002; Reid, 2009). The genus Coendou is poorly differentiated from the genus Sphiggurus, so they are often grouped. Sphiggurus is occasionally considered a subgenus and a junior synonym of Coendou (Roze, 1997; Voss et al., 2013). Molecular differences between both genera provide evidence of their evolutionary distinction to justify their separation (Bonvicino et al., 2002). However, several authors still consider the genus Sphiggurus widely accepted (Wilson \& Reeder, 2005; Ceballos \& Arroyo-Cabrales, 2012); therefore, we follow these authors in this study.

Sphiggurus mexicanus occurred in both coastal plains (Gulf and Pacific) from Mexico to Costa Rica and Panama (Hall, 1981; Reid, 2009). It inhabits different types of vegetation, including the high evergreen forest, the semideciduous forest, tropical dry forest, mangrove forest, cloud forest (Riechers-Pérez, 2004; Faller-Menéndez et al., 2005; Lira-Torres, 2006; Ramírez-Bravo, 2012), coastal sand dunes, grasslands (Briones-Salas \& Sánchez-Cordero, 2004), and temperate and pine-oak forests (Monterrubio-Rico et al., 2010) from lowlands to 3 200m (Juárez, G., 2005; Reid, 2009).

Few studies are related to $S$. mexicanus and refer basically to its distribution (Leopold, 2000; Ramírez-Bravo, 2012); reproductive behavior (Starret, 1967; Álvarez del Toro, 1991); reproductive data (Hall \& Dalquest, 1963; Jones et al., 1974); food habits (Gaumer, 1917; Monterrubio-Rico et al., 2010); occupation records in guava, banana, and cereal crops (Starret, 1967); its use by local people (Grimwood, 1969; Álvarez del Toro, 1991; Puc-Gil \& Retana-Guiascón, 2012); and biological aspects (Mendoza-Cárdenas, 2006). In the Tehuantepec Isthmus, $S$. mexicanus is not common, and only the observation of a specimen was documented in 2006 in riparian vegetation (López et al., 2009). In general, there are only few records of $S$. mexicanus specimens deposited in different mammal collections (number of specimens in parenthesis): University of Kansas, Biodiversity Institute, KU (19); Universidad Nacional Autónoma de México, Colección Nacional de Mamíferos, CNMA (14); El Colegio de la Frontera Sur, ECOSUR (12); Secretaría de Medio Ambiente, Vivienda e Historia Natural, CZRMA (5); Universidad Nacional Autónoma de México, Museo de Zoología "Alfonso L. Herrera", MZFC-M (3); Instituto Politécnico Nacional, Escuela Nacional de Ciencias Biológicas, ENCB, and 
Instituto Nacional de Investigaciones sobre Recursos Bióticos, INIREB (2 each one); and Field Museum of Natural History Chicago, FMNH; Louisiana State University Museum of Natural Science, LSUMZ; Museum of Comparative Zoology (Harvard University), MCZ; Universidad Autónoma Metropolitana, Unidad Iztapalapa, UAMI (one each).

In order to assess the status and change rates (land use and vegetation cover) in the habitat of the tropical porcupine $S$. mexicanus in the lagoon area of the Tehuantepec Isthmus in Oaxaca, we proposed to (1) detail the characteristics of its habitat through the specimens observed in a mosaic of semi-deciduous forest associated to palm and tropical dry forest; (2) determine the change rates in land use and vegetation in its habitat; and (3) know habitat availability and the formation of potential corridors for the movement of species individuals. The results of our study can be useful for conservation and management of this threatened taxon and its habitat.

\section{MATERIALS AND METHODS}

The study area is located around Montecillo Santa Cruz, Municipality of San Francisco del Mar in the Northern part of the Inferior Lagoon in Oaxaca between $16^{\circ} 2240.3 \mathrm{~N}-94^{\circ} 3528.3 \mathrm{~W}$ and $16^{\circ} 2133.6 \mathrm{~N}-94^{\circ} 3417.9 \mathrm{~W}$ at an altitude of $24 \mathrm{~m}$ (Lorenzo et al., 2000). The climate in this area is warm and sub-humid with rains in summer, characterized by strong drought seasons from March to May and rainfalls from June to October (García, 1981; Millán, 1993). The average annual temperature is $25^{\circ} \mathrm{C}$ with a total annual precipitation of $932.2 \mathrm{~mm}$ (García, 1981). The area is characterized by a flat terrain, two perennial water bodies (lakes and streams), and an intermittent stream. Sorghum and maize crops are also found in the area (Rzedowski, 1994; Pérez-García et al., 2001; López et al., 2009; Sántiz et al., 2012).

Field work: We made six general faunal surveys (1) 9-12 February 2011; (2) 7-10 February 2012; (3) 24-27 November 2012;
(4) February 25 to March 2, 2013; (5) 24-30 August 2013, and (6) 22-25 April 2014. Daytime routes were on foot in the study area when searching for mammals, and especially in the vegetation fragments where locals had performed porcupine sightings during their working hours. These routes were covered beginning at 9:00h and ending at 15:00h for five consecutive days with a total of $52 \mathrm{~km}$ in 26 days, $2 \mathrm{~km}$ per day. During the surveys, we directly observed $S$. mexicanus individuals, and each specimen was recorded using a manual global positioning system unit (Garmin GPS 12 Magellan, precision 10m, California, USA). Porcupines were not common in the study area, and only few individuals were recorded during four years of study; therefore, it was not possible to make additional systematic analyses and obtain abundance and density population data. Moreover, its traces (footprints and fecal pellets) were difficult to see since the type of soil consisting of leaf litter did not allow it.

Habitat characteristics: To register and describe vegetation composition and structure in the porcupine habitat (where the specimens were directly observed), we used the line intercept method (Canfield, 1941). A total of 14 transects of $50 \mathrm{~m}$ in length were settled with a global positioning system receiver (GPS eTrex Vista, 3-15m accuracy, Garmin, Kansas, USA). We calculated the value of importance of plant species (herbs, vines, shrubs, and trees) through values of relative density, relative cover, and relative frequency (Canfield, 1941). Each plant species was photographed, and a sample of some species was collected and transported to the Herbarium of El Colegio de la Frontera Sur (ECOSUR), San Cristóbal de Las Casas, Chiapas for their identification. Taxonomic determination of the plant species was done through comparison of the samples collected with herbarium specimens and identification keys (Hitchcock, 1971; Standley et al., 1974; Cabrera et al., 1982; McVaugh, 1987; Ackerman et al., 1995; Torres-Colín et al., 1997; Stevens et al., 2001; Pennington \& Sarukhán, 2005; Dávila et al., 2006; Rico-Arce, 
2007). We count with the assistance and advice of experts.

Vegetation and land use: We classified vegetation and land use using two satellite images of the study area. The first was a multispectral image LANDSAT ETM + 7 of 1986 with $15 \mathrm{~m}$ of spatial resolution. For the second period (2012), we used a high-resolution image SPOT 5 with a four-band radiometric resolution and a space of $10 \mathrm{~m}$. The interpretation of vegetation types and land use was processed with the interdependent classification method, which consists of updating the interpretation of an earlier date with the image of the next date (FAO, 1996) through stratification of the two scenes with the software ArcGIS 9.3 (ESRI, 1993).

From this approach, we delimited polygons for each type of vegetation and land use avoiding subjectivity in delimiting each thematic class. For the change rates analysis, we carried out a spatial restitution of the image SPOT pixel size at $15 \mathrm{~m}$ to homogenize the spatial structure of both images. To identify changes in land use and vegetation, both layers were generalized in nine thematic classes based on the classification of the vegetation in Oaxaca according to Rzedowski (1994) for the area using the Land Change Modeler in IDRISI Selva module ver. 17.02.

Estimation of change rates: The equation proposed by FAO (1996) was used to obtain the change rates for each type of vegetation and land use, and it was expressed as:

$$
\delta_{\mathrm{n}}=\left[\left(\mathrm{S}_{2} / \mathrm{S}_{1}\right)^{1 / \mathrm{n}}-1\right]^{*} 100
$$

Where $\delta_{n}=$ change rate expressed as percentage, $\mathrm{S}_{1}=$ surface in the initial time period; $\mathrm{S}_{2}=$ surface in the last time period; $n=$ number of years between the two periods.

The rates expressed surface changes for each type and year and were assessed as percentage. This procedure was applied for all habitats in vegetation types and land use: temporal agriculture (Crop), human settlements
(HS), water bodies (W), induced grassland (Grss), savannas (Sav), tropical dry forests (DF), mesquite grassland (Mgrss), semi-deciduous forest (SDF), and water flood areas (Wfa). The results describe the transitions among all land coverage, including the forest (Velasquez et al., 2002). To determine if a dependency existed between both time periods by types, a test of proportions was performed.

Habitat assessment and potential corridors: For habitat assessment, we used the most recent vegetation and land use classification types (based on multispectral image SPOT from 2012), which were based on species specificity to its habitat, determining influence areas (buffers), as sensitivity to inhospitable habitats, for example, to sites with human impact. Likewise, we evaluated the development of potential corridors in the habitat, and the ability to cross gaps (unsuitable habitat) within the influence areas, so the species could move within these areas. The resulting map provides a preliminary assessment of the habitat, classifying it into the following categories: suitable habitat, corridor, and unsuitable habitat.

According to the habitat analysis and field observations, the following parameters were established: those types of vegetation and land use that do not allow the presence of the species or their mobility within the area, such as agricultural areas, induced grassland, human settlements, and savannas, which were considered as unsuitable habitats; a core area from five to 20.2 ha for suitable habitat patches and a distance of $120 \mathrm{~m}$ minimum from the edge of the patch as influence area (buffer) was considered with regard to areas not suitable for the species. The corridors were contemplated from 30 to $80 \mathrm{~m}$ wide.

\section{RESULTS}

A total of 11 adult porcupine specimens were directly observed in the study area during the four-year period (2011-2014); 10 of them were observed in a mosaic of semi-deciduous forest and palm grove, and one in a tropical 
dry forest at altitudes from 5 to $30 \mathrm{~m}$. It was not possible to identify sex or reproductive status of the porcupines. Two porcupines were observed above the tree Andira inermis (one in November 2012 and the other in February 2013); six above the palms (Sabal mexicana) with vines (two in February 2011, two in February 2013, and two in August 2013); two more were observed on trees in August 2013, one above the oak tree (Ehretia tinifolia) and the other one above the white oak tree (Licania arborea); and one above the guanacaste tree (Enterolobium cyclocarpum) in April 2014.

In semi-deciduous forests associated to palms, we collected several plants along transects and identified the plant species of the porcupine habitat. Using the line intersect method (Canfield, 1941), we recorded a total of 64 species (44 trees, nine vines, seven herbs, four shrubs), of which nine species were determined at family level (two vines and seven trees), 17 at genus level, and 38 at species level. The vine Bunchosia lanceolata was the species showing the highest value of importance (41.85), followed by the trees Guazuma ulmifolia (22.71), Dalbergia glabra (18.05), and Enterolobium cyclocarpum (17.02). The species with the lowest value of importance were the tree Amphitecna sp. (0.64) and the herbs Justicia sp. (0.64), and Eupatorium sp. (0.65; Table 1). The records of the porcupines are shown in figure 1.

The type of vegetation and land use that showing the highest change rate was $\operatorname{Sav}\left(\delta_{n}=-\right.$ $2.9 ;-650.3 \mathrm{ha})$. However, when the change rate was considered, Mgrss $\left(\delta_{n}=-0.99 ;-283.3 \mathrm{ha}\right)$ resulted in the habitat with the greatest transformation, followed by DF and SDF with a similar rate for the time interval of 26 years $\left(\delta_{n}=-0.89\right.$; $-370.2 \mathrm{ha}$ and $\delta_{\mathrm{n}}=-0.87 ;-101.45 \mathrm{ha}$, respectively). By contrast, the land use showing greater increases were Grss $\left(\delta_{\mathrm{n}}=2.31 ; 653.4 \mathrm{ha}\right)$ and Crop $\left(\delta_{n}=4.13\right.$; 646.7ha; Fig. 1; Table 2). Plant associations that suffered the most important changes in this period were: the savanna (Sav), which was transformed to induced grassland (Grss; 561.2ha); followed by Grss to temporal agriculture (Crops; 313.4ha); and mesquite grassland (Mgrss) and tropical dry forests (DF) that were transformed to induced grasslands (223.4ha and 218.1ha, respectively; Table 3).

The evaluation of the habitat analysis showed that 4400.28 ha of the total area (6 195.8ha) corresponded to habitats that were not suitable for the species to be used for movement, finding resources, or refuge. These

TABLE 1

Values of relative density, relative cover, relative frequency, and importance of each plant species established in plantporcupine association in southern Tehuantepec Isthmus, Oaxaca, Mexico

\begin{tabular}{clcccc} 
Live Form & \multicolumn{1}{c}{ Species } & $\begin{array}{c}\text { Relative } \\
\text { density }\end{array}$ & $\begin{array}{c}\text { Relative } \\
\text { cover }\end{array}$ & $\begin{array}{c}\text { Relative } \\
\text { frequency }\end{array}$ & $\begin{array}{c}\text { Importance } \\
\text { value }\end{array}$ \\
Tree & Ficus insipida Willd. & 0.49 & 2.93 & 0.78 & 4.20 \\
Tree & Guazuma ulmifolia Lam. & 6.86 & 8.42 & 7.42 & 22.71 \\
Tree & Annona sp. & 0.25 & 0.21 & 0.39 & 0.85 \\
Tree & Capparis baducca L. & 0.25 & 0.18 & 0.39 & 0.82 \\
Tree & Cynometra oaxacana Brandegree & 5.88 & 4.83 & 6.25 & 16.96 \\
Tree & Amphitecna sp. & 0.25 & 0.01 & 0.39 & 0.64 \\
Tree & Bauhinia sp. & 1.72 & 0.85 & 1.95 & 4.51 \\
Tree & Leucaena leucocephala (Lam.) de Wit & 0.74 & 0.52 & 1.17 & 2.43 \\
Tree & Ehretia tinifolia L. & 2.45 & 2.84 & 3.52 & 8.80 \\
Tree & Andira inermis (W. Wright) DC & 2.94 & 4.91 & 5.08 & 12.93 \\
Tree & Enterolobium cyclocarpum (Jacq.) Griseb. & 3.92 & 8.41 & 4.69 & 17.02 \\
Tree & Sabal mexicana Mart. & 4.66 & 2.45 & 4.30 & 11.40 \\
Tree & Ceiba aesculifolia (Kunth) Britten \& Baker f. & 0.74 & 1.10 & 1.17 & 3.01 \\
Tree & Eugenia salamensis Donn. Sm. & 0.98 & 0.57 & 1.17 & 2.72 \\
Tree $\quad$ Phyllantus elsiae Urb. & 4.90 & 3.11 & 5.86 & 13.87
\end{tabular}


TABLE 1 (Continued)

\begin{tabular}{|c|c|c|c|c|c|}
\hline Live Form & Species & $\begin{array}{l}\text { Relative } \\
\text { density }\end{array}$ & $\begin{array}{l}\text { Relative } \\
\text { cover }\end{array}$ & $\begin{array}{l}\text { Relative } \\
\text { frequency }\end{array}$ & $\begin{array}{l}\text { Importance } \\
\text { value }\end{array}$ \\
\hline Tree & Randia armata (Sw.) DC. & 1.47 & 0.28 & 1.56 & 3.31 \\
\hline Tree & Randia aculeata $\mathrm{L}$. & 0.49 & 0.67 & 0.78 & 1.94 \\
\hline Tree & Sapindus saponarea $\mathrm{L}$. & 1.96 & 1.15 & 2.34 & 5.46 \\
\hline Tree & Caesalpinia coriaria (jacq).Willd. & 0.74 & 0.64 & 0.39 & 1.76 \\
\hline Tree & Haematoxylum campechianum $\mathrm{L}$. & 1.23 & 0.76 & 1.17 & 3.15 \\
\hline Tree & Bursera simaruba (L.) Sarg. & 0.49 & 0.60 & 0.78 & 1.87 \\
\hline Tree & Spondias purpurea $\mathrm{L}$. & 0.25 & 0.02 & 0.39 & 0.65 \\
\hline Tree & Acacia cornigera $(\mathrm{L}$.$) Willd.$ & 2.45 & 4.56 & 3.13 & 10.13 \\
\hline Tree & Acacia cochliacantha Willd. & 0.25 & 0.27 & 0.39 & 0.91 \\
\hline Tree & Acacia farnesiana $(\mathrm{L}$.$) Willd.$ & 0.49 & 0.36 & 0.78 & 1.63 \\
\hline Tree & Pithecellobium lanceolatum (Willd.) Benth. & 0.25 & 0.10 & 0.39 & 0.74 \\
\hline Tree & Eugenia acapulsensis Steud. & 1.23 & 0.47 & 1.56 & 3.26 \\
\hline Tree & Eupatorium odoratum L. & 0.25 & 0.03 & 0.39 & 0.67 \\
\hline Tree & Lysiloma acapulcense (kunth) Benth. & 0.25 & 0.16 & 0.39 & 0.80 \\
\hline Tree & Licania arborea Seem. & 0.49 & 0.99 & 0.78 & 2.27 \\
\hline Tree & Dalbergia glabra (Mill.) Standley & 4.66 & 8.31 & 5.08 & 18.05 \\
\hline Tree & Leguminous 1 & 0.74 & 0.28 & 0.78 & 1.80 \\
\hline Tree & Leguminous 2 & 0.74 & 1.24 & 1.17 & 3.14 \\
\hline Tree & Leguminous 3 & 0.49 & 0.54 & 0.78 & 1.82 \\
\hline Tree & Leguminous 4 & 0.49 & 0.31 & 0.78 & 1.59 \\
\hline Tree & Crossopetalum sp. & 0.98 & 0.38 & 1.17 & 2.53 \\
\hline Tree & Ipomea sp. 3 & 0.49 & 0.42 & 0.39 & 1.30 \\
\hline Tree & Euphorbiaceae 1 & 0.49 & 0.64 & 0.78 & 1.91 \\
\hline Tree & Boraginacea 1 & 0.49 & 0.09 & 0.78 & 1.37 \\
\hline Tree & Celasthraceae 1 & 1.23 & 0.59 & 1.17 & 2.98 \\
\hline Tree & Tabebuia sp. & 1.23 & 1.08 & 1.56 & 3.87 \\
\hline Tree & Bunchosia sp. 3 & 2.21 & 0.45 & 1.56 & 4.22 \\
\hline Tree & Jathropha sp. & 0.25 & 0.06 & 0.39 & 0.69 \\
\hline Tree & Thevetia sp. & 0.25 & 0.23 & 0.39 & 0.86 \\
\hline Shrubs & Bromelia pinguin $\mathrm{L}$. & 0.74 & 0.22 & 1.17 & 2.13 \\
\hline Shrubs & Acanthocereus pentagonus (L.) Britton \& Rose & 0.25 & 0.05 & 0.39 & 0.69 \\
\hline Shrubs & Malvaviscus arborius Cav. & 0.25 & 0.08 & 0.39 & 0.71 \\
\hline Shrubs & $\begin{array}{l}\text { Schizolobium parahybum (Vell. Conc.) S. F. } \\
\text { Blake }\end{array}$ & 0.25 & 0.04 & 0.39 & 0.67 \\
\hline Vine & Bunchosia lanceolata Turcz. & 9.31 & 25.51 & 7.03 & 41.85 \\
\hline Vine & Cissus cicyoides $\mathrm{L}$. & 1.23 & 0.57 & 1.56 & 3.36 \\
\hline Vine & Pseudocalymma sp. & 8.33 & 2.10 & 3.13 & 13.55 \\
\hline Vine & Cissus verticillata (L.) Nicolson \& C. E. Jarvis & 0.49 & 0.33 & 0.78 & 1.60 \\
\hline Vine & Bignoniaceae 1 & 1.47 & 0.22 & 1.95 & 3.64 \\
\hline Vine & Bignoniaceae 2 & 0.49 & 0.08 & 0.78 & 1.35 \\
\hline Vine & Bunchosia sp. 1 & 0.25 & 0.02 & 0.39 & 0.66 \\
\hline Vine & Bunchosia sp. 2 & 0.74 & 0.74 & 1.17 & 2.65 \\
\hline Vine & Smilax dominguensis Willd & 0.74 & 0.71 & 0.39 & 1.83 \\
\hline Herbs & Eupatorium sp. & 0.25 & 0.01 & 0.39 & 0.65 \\
\hline Herbs & Petiveria alliacea $\mathrm{L}$. & 0.25 & 0.43 & 0.39 & 1.07 \\
\hline Herbs & Bauhinia sp. 2 & 8.33 & 0.52 & 0.39 & 9.25 \\
\hline Herbs & Tetramerium obovatum T.F. Daniel & 1.23 & 0.14 & 0.78 & 2.15 \\
\hline Herbs & Justicia $\mathrm{sp}$ & 0.25 & 0.01 & 0.39 & 0.64 \\
\hline Herbs & Setarea $\mathrm{sp}$ & 0.98 & 1.20 & 1.17 & 3.36 \\
\hline Herbs & Muhlenbergia sp. & 0.25 & 0.02 & 0.39 & 0.66 \\
\hline
\end{tabular}



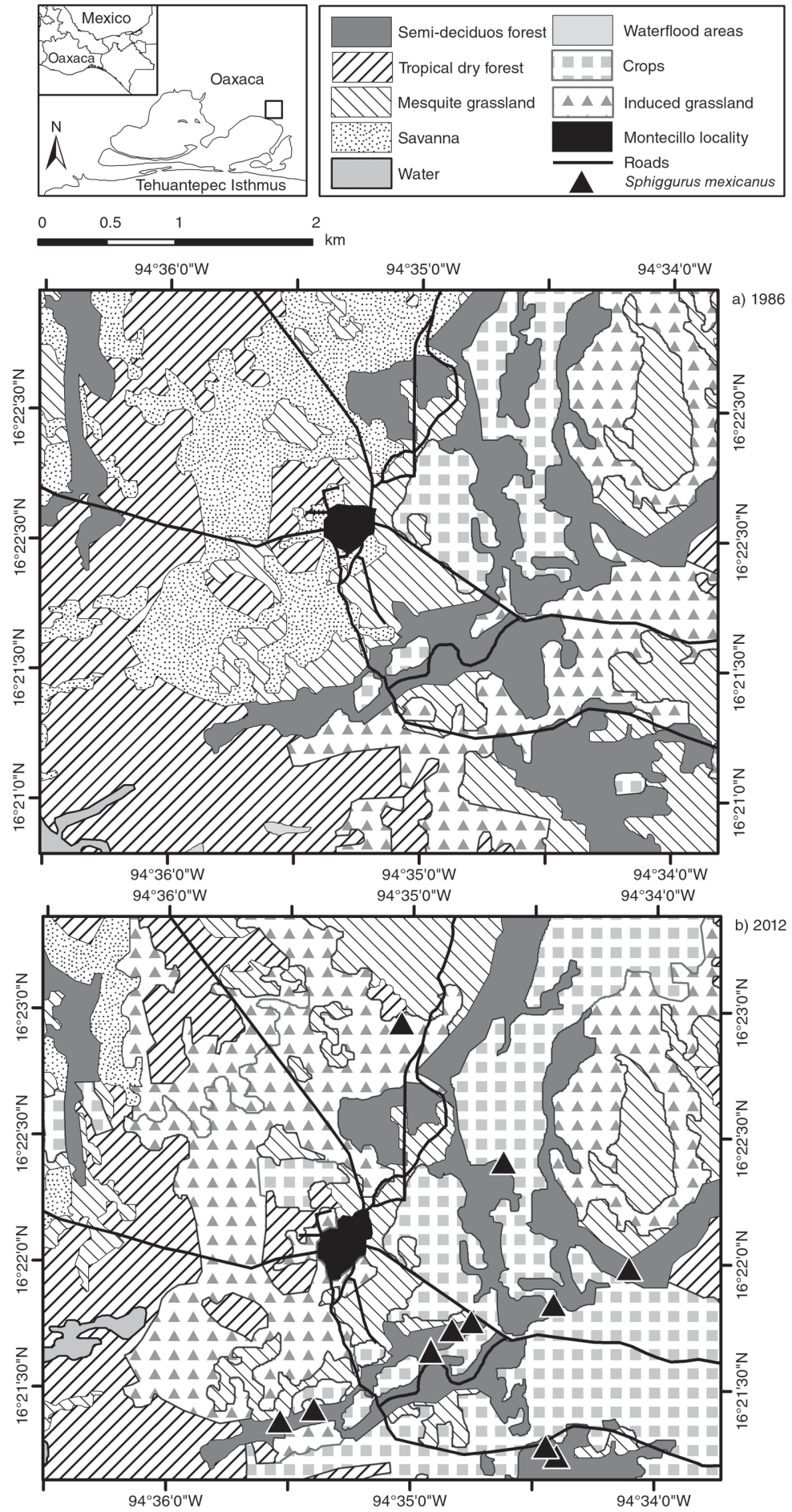

Fig. 1. Changes in types of vegetation and land use of the study area in southern Tehuantepec Isthmus, Oaxaca, Mexico throughout two time periods (1986 and 2012). Images Landsat TM for 1986 and SPOT for 2012, black triangles=records of Sphiggurus mexicanus observed. 
TABLE 2

Surface (ha) and change rates $\left(\delta_{n}\right)$ for each period analyzed (1986 and 2012) by types of vegetation and land use (described in text) in southern Tehuantepec Isthmus, Oaxaca, Mexico

\begin{tabular}{ccccc} 
Types of vegetation and land use & Area in 1986(\%) & Area in 2012(\%) & Difference (ha) & $\delta_{\mathrm{n}}$ \\
SDF & $500.24(8.1)$ & $398.79(6.44)$ & -101.45 & -0.87 \\
DF & $1786.72(28.8)$ & $1416.48(22.86)$ & -370.24 & -0.89 \\
Mgrss & $1240.53(20.0)$ & $957.17(15.45)$ & -283.36 & -0.99 \\
Sav & $1215.24(19.6)$ & $564.86(9.12)$ & -650.38 & -2.90 \\
Grss & $805(13.0)$ & $1458.4(23.54)$ & 653.40 & 2.31 \\
Crop & $346.95(5.6)$ & $993.69(16.04)$ & 646.74 & 4.13 \\
HS & $9.495(0.2)$ & $13.18(0.21)$ & 3.6 & 1.27 \\
W & $255.8(4.1)$ & $356.89(5.76)$ & 101.09 & 1.29 \\
Wfa & $35.95(0.6)$ & $36.47(0.6)$ & 0.52 & 0.06 \\
Total & $6195.93(100.0)$ & $6195.93(100.0)$ & & \\
\hline
\end{tabular}

TABLE 3

Matrix of change for each type of vegetation and land use (described in text) in southern Tehuantepec Isthmus, Oaxaca, Mexico for two periods (1986 and 2012)

\begin{tabular}{|c|c|c|c|c|c|c|c|c|c|c|c|}
\hline & \multicolumn{10}{|c|}{2012} & \multirow{2}{*}{ Total } \\
\hline \multirow{11}{*}{$\stackrel{\circ}{\stackrel{2}{=}}$} & & SDF & DF & Mgrss & Sav & Grss & Crop & HS & W & Wfa & \\
\hline & SDF & 398.7 & 0.2 & 35.2 & 0.2 & 8.2 & 57.4 & & & & 500.2 \\
\hline & $\mathrm{DF}$ & & 1415.0 & 25.8 & 22.1 & 218.1 & 104.1 & & 1.4 & & 1786.7 \\
\hline & Mgrss & & & 809.1 & 18.2 & 223.4 & 182.9 & 3.0 & 1.6 & 1.9 & 1240.5 \\
\hline & $\mathrm{Sav}$ & & 1.2 & 16.7 & 524.2 & 561.2 & 13.4 & 0.6 & 94.0 & 3.7 & 1215.2 \\
\hline & Grss & & & 57.7 & & 433.8 & 313.4 & & & & 805.0 \\
\hline & Crop & & & 11.2 & & 13.4 & 322.2 & & & & 346.9 \\
\hline & HS & & & & & & & 9.5 & & & 9.5 \\
\hline & W & & & 0.9 & & & & & 254.8 & & 255.8 \\
\hline & Wfa & & & 0.2 & & & & & 4.9 & 30.7 & 35.9 \\
\hline & Total & 398.79 & 1416.49 & 957.17 & 564.86 & 1458.41 & 993.69 & 13.19 & 356.90 & 36.4 & 6195.9 \\
\hline
\end{tabular}

The values correspond to transformations considered between the two time periods.

environments are primarily anthropogenic habitats, as urban areas, temporal agriculture, and induced grassland, as well as those native habitats as mesquite grasslands, savannas, and water bodies. This analysis showed that only 1 501.93ha can be considered suitable habitats with structural conditions (coverage, surface, distances to transformed areas) to maintain viable populations of $S$. mexicanus, and 293.6ha as corridors for the current conditions of the area (Fig. 2).

\section{DISCUSSION}

In the study area the porcupines occur in semi-deciduous forest associated to palms and tropical dry forest characterized by vegetation bordering streams with perennial flow, trees from 10 to $20 \mathrm{~m}$ tall as Enterolobium cyclocarpum, Andira inermis, Cynometra oaxacana and Ficus insipida (Pérez-García et al., 2001), and soils with a thin layer of organic matter formed by the large amount of leaves that fall from 

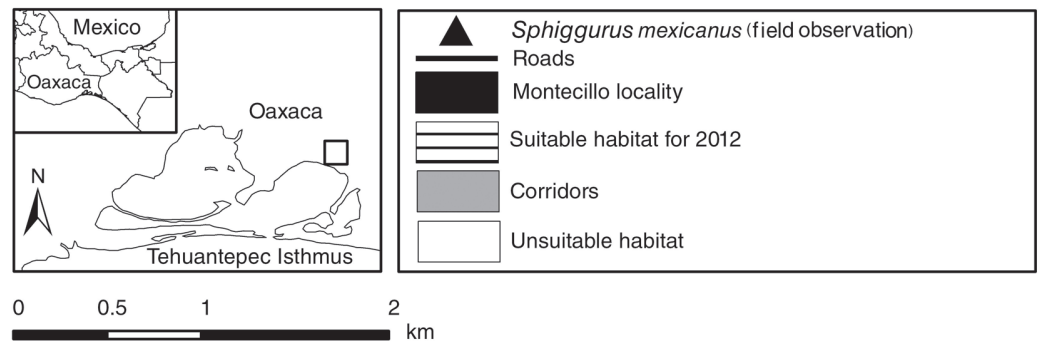

$\mathrm{km}$

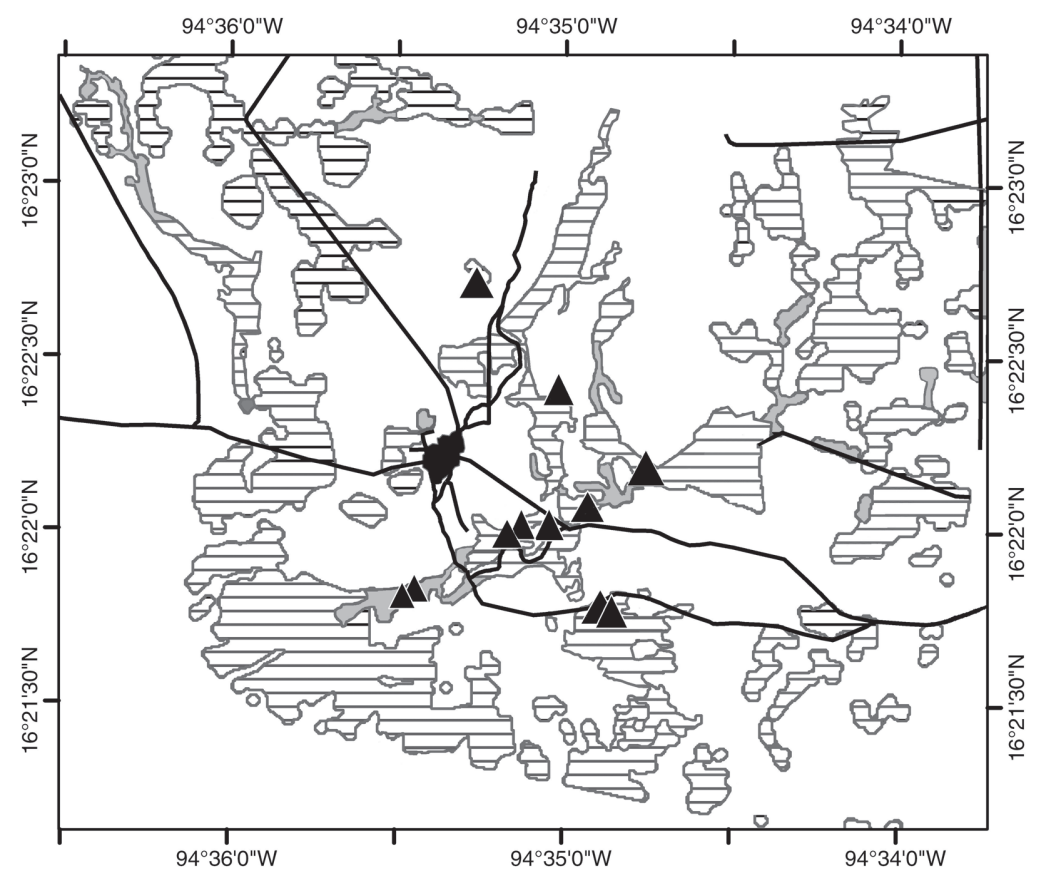

Fig. 2. Habitat evaluation for Sphiggurus mexicanus based on multispectral image SPOT from 2012. The reduction of habitat shows since 1986.

the trees (Flores \& Espejel, 1994). Porcupines were observed resting during the day on large trees (greater than $10 \mathrm{~m}$ tall) and palms (seven meters tall approximately) surrounded by many vines that serve as resting sites and facilitate their mobility since the species has a prehensile tail (Aranda, 2000; Monterrubio-Rico et al., 2010); thus the vine (Bunchosia lanceolata) and tree species used by the porcupine were recorded in this study with the most important values, and all these species favor their optimal requirements (in composition and vegetative cover) and natural development.
In our study, the zapotillo (Bunchosia lanceolata), the guazimo (Guazuma ulmifolia), the guanacaste (E. ciclocarpum), and the vine (Dalbergia glabra) were the species with the highest values of importance in the porcupine habitat. In contrast, in Michoacán, the species with the highest density of the arboreal layer were white oak (Licania arborea), laurel (Cordia alliodora), and the breadnut or ramón (Brosimum alicastrum) for both deciduous and semi-deciduous tropical forest; and the palo mulato or papelillo (Bursera instabilis) in tropical dry forest (Mendoza-Cárdenas, 2006). 
Porcupine records confirm the species in this study prefers semi-deciduous forests as habitat. Although one porcupine was observed in tropical dry forest, it can occasionally be used by the proximity of the semi-deciduous forest and the presence of vegetation cover. However, close to our study area (approx. $28 \mathrm{~km}), S$. mexicanus has been registered only in well preserved tropical dry forest (Cortés, 2009). Additional records for the species in Oaxaca (77km from our study area) have been recorded in semi-deciduous and tropical dry forests (Lira-Torres, 2006). In other areas in Mexico, S. mexicanus has been recorded in these habitats without any significant difference with respect to habitat preference (Mendoza-Cárdenas, 2006).

The vegetation types where the porcupines were observed have been mentioned in previous studies for the species (Briones-Salas \& Sánchez-Cordero, 2004; Castro-Arellano \& Medellín, 2005; Colchero et al., 2005; Juárez, G., 2005); however, the induced grassland and crops did not show an arboreal layer to cover the requirements of the porcupines in the study area. Additionally, we recorded the presence of two opossum species (Didelphis marsupialis and Philander opossum) that coexist with porcupines, but these records can be occasional since opossums are generalists in their food, occupy more habitats, and their movements are much higher than those of the porcupines.

The occurrence of $S$. mexicanus in vegetation types of specific characteristics makes it vulnerable to habitat changes, which might explain the few existing records in Mexico. In the databases available in the Internet, as the Unidad de Informática para la Biodiversidad (UNIBIO), of the Instituto de Biología, Universidad Nacional Autónoma de México (http:// unibio.unam.mx/) and the Global Biodiversity Information Facility (GBIF; http://www.gbif. org/) we found 98 records in total, of which 61 are voucher specimens in mammal collections and the rest (37) were visual records.

In general, change rates in vegetation types and land use in the study area have been largely caused by humans, as the transformation of the habitat in a period of 26 years has been for agricultural (crops) and livestock activities (opening of pasture areas). In particular, the habitat of $S$. mexicanus, semi-deciduous and tropical dry forests, has declined in 101 and 370ha, respectively, by transforming them to temporal agriculture (Crop), mesquite grassland (Mgrss), and induced grassland (Grss). Therefore, the types of vegetation and land use most benefited by habitat transformation were induced grasslands (Grss) and temporal agriculture (Crop).

The habitat evaluation showed that some corridors connected suitable habitats for the species (semi-deciduous and tropical dry forests); however, some specimens could be isolated because the patches where they were observed did not have any corridor. It was possible to observe patches (and corridors) crossed by roads that might be affected (in a near future) by deforestation due to their easy access. This aspect could cause a severe ecosystem fragmentation (with the creation of new human settlements, conversion of the use of soil, destruction of natural habitats), microclimate changes, reduction of native fauna populations, mobility of organisms, and dispersal and limited colonization (Arroyave et al., 2006).

Corridors might provide these benefits to adjacent populations over large timescales even if they lessen the survival and reproductive success of most of the individuals that use them (Chetkiewicz et al., 2006). The corridors identified in the study area are essential for dispersal between individuals to sustain their demographic population (Hanski, 2001), and for genetic exchange to maintain gene flow (Mills \& Allendorf, 1996).

It is important to mention that other studies for the home range size determination of $S$. mexicanus are required through a more systematic sampling to make the modeling of habitat evaluation more accurate. Apparently and by comments from local residents, the tropical porcupine population has been seen in those vegetation patches for 50 years. However, it is important to determine the size of the 
population, its movements, and habitat requirements that are necessary to have healthy and viable breeding. In this sense, the search for patterns that might be influenced by the various processes within the area is required.

The increase of human settlements, the bad land management, and lack of control of productive activities, such as extensive ranching and the burning of pastures for seasonal agriculture have resulted in habitat loss and fragmentation in the study area (Lorenzo et al., 2008; Rioja et al., 2011; Carrillo-Reyes et al., 2012). Although porcupines are not hunted, their habitat (semi-deciduous forest and palms and tropical dry forest) is disappearing at an accelerated rate due to excessive logging to expand the sorghum planting land area ( $\mathrm{J}$. Antonio, pers. comm.).

If the current trends of habitat destruction of the porcupines in the study area do not change, the species may be at serious risk of disappearing in the short term, which could be aggravated because their populations are not in a protected natural area. The semi-deciduous forest with palms and tropical dry forest are used by porcupines, so they should be considered as priority areas for species management and conservation, particularly those areas that have corridors and are not crossed by roads. A sustainable development of human activities such as agriculture is necessary to avoid the loss of vegetation cover.

\section{ACKNOWLEDGMENTS}

We thank the municipal and communal authorities of Montecillo Santa Cruz, San Francisco del Mar, Oaxaca, and especially to J. Antonio, E. Antonio, and the Gutierrez Vázquez and Antonio Gutierrez families for their collaboration. M. Martínez and H. Ocaña for their help with the identification of the plant species; M. C. Ruiz and X. Sántiz for their help in fieldwork; D. Dorantes for editorial services in English; T. Rioja and two anonymous reviewers for their very useful comments for improving the manuscript.

\section{RESUMEN}

Causas y consecuencias de las tasas de cambio en el hábitat del puerco espín tropical amenazado, Sphiggurus mexicanus (Rodentia: Erethizontidae), en Oaxaca, México: implicaciones para su conservación. Los cambios de uso del suelo por actividades humanas, han sido de las principales causas de la degradación, reducción y fragmentación de los hábitats y poblaciones de fauna silvestre. En el Istmo de Tehuantepec, Oaxaca, el hábitat del puercoespín tropical Sphiggurus mexicanus, se encuentra sometido a cambios de cobertura vegetal y uso del suelo, que están causando la reducción y fragmentación de su hábitat. Debido a ello, estimamos las tasas de cambio de la cobertura vegetal y uso del suelo $\left(\delta_{n}\right)$, y evaluamos la disponibilidad del hábitat y de corredores vegetales potenciales para los posibles movimientos del puercoespín tropical y evitar su aislamiento. En el área de estudio el tipo de vegetación con mayor valor de tasa de cambio fue la sabana $\left(\delta_{n}=-2.9\right)$, transformado en pastizal inducido. Adicionalmente, observamos puercoespínes (desde 2011) en selva mediana subperennifolia $\left(\delta_{\mathrm{n}}=-0.87\right)$ y selva baja caducifolia $\left(\delta_{n}=-0.89\right)$, los cuales han sido transformados en áreas de cultivo, selva baja espinosa y pastizal inducido. Caracterizamos la vegetación del hábitat del puercoespín, registrando un total de 64 especies vegetales (44 árboles, nueve bejucos, siete hierbas y cuatro arbustos), de los cuales, el bejuco Bunchosia lanceolata, presentó los valores más altos de importancia (41.85), seguidos por los árboles Guazuma ulmifolia (22.71), Dalbergia glabra (18.05), y Enterolobium cyclocarpum (17.02). El análisis de evaluación de hábitat y corredores potenciales mostró que solo 1 501.93ha pueden considerarse como hábitats adecuados con condiciones estructurales (de cobertura, superficie y distancias a áreas transformadas) para mantener poblaciones viables de $S$. mexicanus; y 293.6ha como corredores. La destrucción del hábitat del puerco espín en el área de estudio está incrementándose por la tala excesiva, por lo tanto, es prioritario emprender acciones para la conservación y manejo del taxón y su hábitat.

Palabras clave: asociaciones vegetales, Sphiggurus mexicanus, corredor, evaluación de hábitat, Istmo de Tehuantepec, puerco espines tropicales, selección, uso.

\section{REFERENCES}

Ackerman, B. A., Miranda, S. J., Jaramillo, L. V., Rodríguez, R. A. M., \& Aragón, M. L. (1995). Las Gramíneas de México. Tomo IV. México, D. F.: Secretaria de Agricultura Ganadería y Desarrollo Rural, Subsecretaria de Agricultura y Ganadería, Comisión Técnico Consultiva de Coeficientes de Agostadero.

Álvarez del Toro, M. (1991). Los mamíferos de Chiapas. Ciudad de México/Chiapas. Instituto Chiapaneco de Cultura, México: Gobierno del estado de Chiapas. 
Consejo Estatal de Fomento a la Investigación y Difusión de la Cultura.

Aranda, M. (2000). Huellas y otros rastros de mamíferos grandes y medianos de México. México: CONABIO, Instituto de Ecología.

Arroyave, M. P., Gómez, C., Gutiérrez, M. E., Múnera, D. P., Zapata, P. A., Vergara, I. C., Andrade, L. M., \& Ramos, K. C. (2006). Impactos de las carreteras sobre la fauna silvestre y sus principales medidas de manejo. Revista EIA, 5, 45-57.

Bonvicino, C. R., Penna-Firme, V., \& Braggio, E. (2002). Molecular and Karyologic Evidence of the Taxonomic Status of Coendou and Sphiggurus (Rodentia: Hystricognathi). Journal of Mammalogy, 83, 1071-1076.

Briones-Salas, M. \& Sánchez-Cordero, V. (2004). Mamíferos. In A. J. García-Mendoza, M. J. Ordoñez, \& M. Briones-Salas (Eds.), Biodiversidad de Oaxaca (pp. 423-447). México, D. F.: Instituto de Biología, UNAM, Fondo Oaxaqueño para la Conservación de la Naturaleza, World Wildlife Fund.

Cabrera, E. F., Téllez, V., \& Sousa, M. (1982). Imágenes de la Flora Quintanarroense. Chetumal, Quintana Roo: Centro de Investigaciones de Quintana Roo, Secretaría de Desarrollo Urbano y Ecología.

Canfield, R. (1941). Application of the line interception method in sampling range vegetation. Journal of Forestry, 39, 338-394.

Carrillo-Reyes, A., Lorenzo, C., Rioja-Paradela, T. M., Naranjo, E., \& Pando, M. (2012). Uso de hábitat de la liebre en peligro de extinción, Lepus flavigularis: implicaciones para su conservación. Therya, 3, 113-125.

Castro-Arellano, I. \& Medellín, R. A. (2005). Philander opossum (Linnaeus, 1758). In G. Ceballos \& G. Oliva (Eds.), Los mamíferos silvestres de México (pp. 111113). México, D. F.: Fondo de Cultura Económica, Comisión Nacional para el Conocimiento y Uso de la Biodiversidad.

Ceballos, G., Arroyo, J. C., \& Medellín, R. A. (2002). Mamíferos de México. In G. Ceballos \& J. A. Simonetti (Eds.), Diversidad y Conservación de los Mamíferos Tropicales (pp. 377-413). México, D. F.: Universidad Nacional Autónoma de México y Comisión Nacional para el Conocimiento y Uso de la Biodiversidad.

Ceballos, G. \& Arroyo-Cabrales, J. (2012). Lista actualizada de los mamíferos de México. Revista Mexicana de Mastozoología (nueva época), 2, 27-80.

Chetkiewicz, C. L. B., St. Clair, C. C. \& Boyce, M. S. (2006). Corridors for Conservation: Integrating Pattern and Process. Annual Review of Ecology, Evolution, and Systematics, 37, 317-342.
Colchero, F., O'Farrill, G., \& Medellín, R. A. (2005). Didelphis marsupialis Linnaeus 1758. In G. Ceballos \& G. Oliva (Eds.), Los mamíferos silvestres de México (pp. 106-108). México, D. F.: Fondo de Cultura Económica, Comisión Nacional para el Conocimiento y Uso de la Biodiversidad.

Cortés, M. (2009). Diversidad de mamíferos medianos y grandes en dos sitios con diferente grado de conservación en La Venta, Juchitán, Oaxaca (Tesis de Maestría). Centro Interdisciplinario de Investigación para el Desarrollo Integral Regional Unidad Oaxaca. Instituto Politécnico Nacional, México.

Dávila, P., Mejía-Saulés, M. T., Gómez-Sánchez, M., Valdés-Reyna, J., Ortiz, J. J., Morín, C., Castrejón, J., \& Ocampo, A. (2006). Catálogo de las Gramíneas de México. México. D. F.: Universidad Nacional Autónoma de México, Comisión Nacional para el Conocimiento y Uso de la Biodiversidad.

Emmons, L. H. \& Feer, F. (1997). Neotropical Rainforest Mammals. A Field Guide. Chicago, Illinois, USA: University of Chicago Press.

Environmental Systems Research Institute (ESRI). (1993). ArcGIS. Environmental Systems Research Institute, Redlands, California, USA.

Faller-Menéndez, J. C., Urquiza-Haas, T., Chávez, C., Johnson, S., \& Ceballos, G. (2005). Registros de mamíferos en la reserva privada El Zapotal, en el noreste de la Península de Yucatán. Revista Mexicana de Mastozoología, 9, 128-140.

FAO. (1996). Forest resources assessment 1990. Survey of tropical forest cover and study of change processes. FAO Forestry Paper, vol. 130.

Flores, J. L. \& Espejel, I. (1994). Etnoflora Yucatanense. Tipos de vegetación de la Península de Yucatán. Universidad Autónoma de Yucatán, México. Sostenibilidad Maya. Fascículo 3.

Galicia, L., García, R. A., Gómez-Mendoza, L., \& Ramírez, M. I. (2007). Cambio de uso del suelo y degradación ambiental. Ciencia, 58(4), 50-59.

García, E. (1981). Modificaciones al sistema de clasificación climática de Köppen (para adaptarlo a las condiciones de la República Mexicana). E. García (Ed.). México, D. F.: Talleres Larios.

Gaumer, G. F. (1917). Monografia de los mamíferos de Yucatán. México: Departamento de Talleres Gráficos de la Secretaría de Fomento.

Gómez-Martínez, E. (2005). Diagnóstico Regional del Istmo de Tehuantepec: Proyecto Perfiles Indígenas. Oaxaca, México: Centro de Investigaciones y Estudios Superiores en Antropología Social. CIESAS. Unidad Istmo.

González, P. G., Briones-Salas, M., \& Alfaro, A. M. (2004). Integración del conocimiento faunístico del estado. In A. J. García-Mendoza, M. J. Ordóñez, \& 
M. Briones-Salas (Eds.). Biodiversidad de Oaxaca (pp. 449-466). México: Instituto de Biología, UNAM-Fondo Oaxaqueño para la Conservación de la Naturaleza-World Wildlife Fund, México.

Grimwood, I. R. (1969). Notes on the Distribution and Status of some Peruvian Mammals. Special Publication America Community International Wildlife Protection No. 21, v +86 .

Hall, E. R. (1981). The mammals of North America, Volume 1 and 2. New York, USA: John Wiley and Sons.

Hall, E. R. \& Dalquest, W. W. (1963). The mammals of Veracruz. Publications of the University of Kansas Museum of Natural History, 14, 165-362.

Hanski, I. (2001). Population dynamic consequences of dispersal in local populations and in metapopulations. In J. Clobert, E. Danchin, A. A. Dhondt, \& J. D. Nichols (Eds.), Dispersal (pp. 283-298). Oxford: Oxford University Press.

Hitchcock, A. S. (1971). Manual of the Grasses of the United States. Volumes One and Two. Washington, D. C., USA: Albert Spear. Publisher: IDC.

INEGI. (2005). Carta de uso actual del suelo y vegetación Serie III. México.

INEGI. (2012). Conjunto de datos vectoriales de uso del suelo y vegetación escala 1:250000, serie v (capa unión). México.

IUCN (International Union for Conservation of Nature). (2012). Sphiggurus mexicanus. In IUCN 2012. IUCN Red List of Threatened Species. Version 2012.2. http://www.iucnredlist.org.

Janzen, D. H. (1983). Coendou mexicanus (Puercoespín, Prehensil-tailed Porcupine). In D. H. Janzen (Ed.), Costa Rican Natural History (pp. 460-461). Illinois, USA: The University Chicago, Chicago.

Jones, J. K. Jr., Genoways, H. H., \& Lawlor, T. E. (1974). Annotated checklist of mammals of the Yucatan Peninsula, Mexico. II. Rodentia. Occasional Paper The Museum Texas Tech University, 22, 1-24.

Juárez-G., J. R. (2005). Coendou mexicanus (Kerr, 1792). In G. Ceballos \& G. Oliva (Eds.), Los mamiferos silvestres de México (pp. 811-812). México, D. F.: Fondo de Cultura Económica, Comisión Nacional para el Conocimiento y Uso de la Biodiversidad.

Leopold, A. S. (2000). Fauna Silvestre de México. Colombia: Pax México.

Lira-Torres, I. (2006). Abundancia, densidad, preferencia de hábitat y uso local de los vertebrados en la Tuza de Monroy, Santiago Jamiltepec, Oaxaca. Revista Mexicana de Mastozoología, 10, 41-66.

López, J. A., Lorenzo, C., Barragán, F., \& Bolaños, J. (2009). Mamíferos terrestres de la zona lagunar del Istmo de Tehuantepec, Oaxaca, México. Revista Mexicana de Biodiversidad, 80, 491-505.
Lorenzo, C., Retana-Guiascón, O., Cervantes, F. A., Vargas, J., \& Portales, G. L. (2000). Status survey of the critically endangered Lepus flavigularis. Final report to Chicago Zoological Society, El Colegio de la Frontera Sur. San Cristóbal de Las Casas, Chiapas, Mexico.

Lorenzo, C., Rioja, T. M., Carrillo, A., \& Cervantes, F. A. (2008). Population fluctuations of Lepus flavigularis (Lagomorpha: Leporidae) at Tehuantepec Isthmus, Oaxaca, Mexico. Acta Zoológica Mexicana (n. s.), 24, 207-220.

McVaugh, R. (1987). Flora Novo-Galiciana, a descriptive account of the vascular plants of western Mexico. Leguminosae. Vol. 5. The University of Michigan, Ann Arbor, USA.

Mendoza-Cárdenas, N. (2006). Estudio de algunos aspectos biológicos del puercoespín (Coendou mexicanus) en el estado de Michoacán, México (Tesis de Licenciatura). Universidad Michoacana de San Nicolás de Hidalgo, México.

Millán, S. (1993). Fiestas de los pueblos indígenas, la ceremonia perpetua. Ciclos festivos y organización ceremonial en el sur de Oaxaca. México, D. F.: Instituto Nacional Indigenista. Secretaría de Desarrollo Social.

Mills, L. S. \& Allendorf, F. W. (1996). The one-migrantper-generation rule in conservation and management. Conservation Biology, 10, 1509-1518.

Monterrubio-Rico, T. C., Ortega-Rodríguez, J. M., Mendoza-Cárdenas, N., Cancino Murillo, R., \& Pérez Arteaga, A. (2010). Distributional and Ecological Records of the Mexican Hairy Dwarf Porcupine (Sphiggurus mexicanus) from Michoacan, Mexico. The Southwestern Naturalist, 55, 139-42.

Ochoa, J. (1993). Diseño de corredores de vida silvestre en bosques productores de maderas de la Guayana venezolana. Memorias del Taller: Corredores de Vida Silvestre en Centroamérica. The Wildlife Society's International Wildlife Management Congress. Heredia, Costa Rica

Pennington, T. D. \& Sarukhán, J. (2005). Árboles Tropicales de México. Manual para la identificación de las principales especies. México, D. F.: Universidad Nacional Autónoma de México y Fondo de Cultura Económica.

Pérez-García, E. A., Meave, J., \& Gallardo, C. (2001). Vegetación y Flora de la Región de Nizanda, Istmo de Tehuantepec, Oaxaca, México. Acta Botánica Mexicana, 56, 19-88.

Puc-Gil, R. A. \& Retana-Guiascón, O. G. (2012). Uso de la fauna silvestre en la comunidad maya Villa de Guadalupe, Campeche, México. Etnobiología, 10, 1-11.

Puth, L. M. \& Wilson, K. A. (2001). Boundaries and corridors as a continuum of ecological flow control: 
lessons from rivers and streams. Conservation Biology, 15, 21-30.

Ramírez-Bravo, O. E. (2012). New records of the mexican hairy porcupine (Coendou mexicanus) and tamandua (Tamandua mexicana) in Puebla, Central Mexico. Western North American Naturalist, 72, 93-95.

Reid, F. A. (2009). A Field Guide to the Mammals of Central America and Southeast México. New York, USA: Oxford University Press.

Rico-Arce, M. L. (2007). A checklist and synopsis of American species of Acacia (Leguminosae: Mimosoideae). México, D. F.: Comisión Nacional para el Conocimiento y Uso de la Biodiversidad (CONABIO).

Riechers-Pérez, A. (2004). Análisis mastofaunístico de la Zona Sujeta a Conservación Ecológica Laguna Bélgica, Chiapas, México. Anales del Instituto de Biología, Universidad Nacional Autónoma de México, Serie Zoología, 75, 363-382.

Rioja, T., Lorenzo, C., Naranjo, E., Scott, L., \& CarrilloReyes, A. (2011). Breeding and parental care in the endangered Tehuantepec jackrabbit (Lepus flavigularis). Western North American Naturalist, 71, 56-66.

Roze, U. (1997). The North American Porcupine. Washington, D. C., USA: Smithsonian Institution Press.

Rzedowski, J. (1994). Vegetación de México. México, D. F.: Limusa-Noriega.

Sántiz, E. C., González-Romero, A., Lorenzo, C., GallinaTessaro, S., \& Cervantes, F. A. (2012). Uso y selección de asociaciones vegetales por la liebre de Tehuantepec (Lepus flavigularis) en Oaxaca, México. Therya, 3, 127-136.

Secretaría de Medio Ambiente y Recursos Naturales (SEMARNAT). (2010). Norma Oficial Mexicana NOM-059-ECOL-2010, Protección ambiental-Especies nativas de México de flora y fauna silvestres- Categorías de riesgo y especificaciones para su inclusión, exclusión o cambio- Lista de especies en riesgo. Diario Oficial de la Federación, Segunda Sección, págs. 1-78, Jueves 30 de Diciembre, México, D. F.
Sorrell, J. (1997). Using geographic information systems to evaluate forest fragmentation and identify wildlife corridor opportunities the Cataraqui watershed. Downsview, Ontario, Canada: Faculty of Environmental Studies. York University, http://www.terraplex. com/epub/pub_sor/.html

Standley, P. C., Williams, L. O., \& Nash, G. D. (1974). Flora of Guatemala. Fieldiana Botany. v. 24, pt. 4. USA: Chicago Natural History Museum.

Starret, A. (1967). Hystricoid, Erethizontoid, Cavioid and Chinchilloid rodents. In S. Anderson \& J. K. Jones, Jr. (Eds.), Recent Mammals of World (pp. 254-272). New York, USA: Ronald Press Co.

Stevens, W. D., Ulloa, C. U., Pool, A., \& Montiel, O. M. (2001). Flora de Nicaragua. Tome I, II, III. Vol. 85. USA: Missouri Botanical Garden Press.

Torres-Colín, R., Torres-Colín, L., Dávila-Aranda, P., \& Villaseñor, J. L. (1997). Listados florísticos de México XVI. Flora del Distrito de Tehuantepec, Oaxaca. México, D. F.: Instituto de Biología, Universidad Nacional Autónoma de México.

Velasquez, A., Mas, J. F., Palacio, J. L., Díaz, J. R., Mayorga, S. R., Alcántara, C., Castro, R., Bocco, G., Ezcurra, E., \& Fernández, T. (2002). Patrones y tasas de cambio de uso del suelo en México. Gaceta Ecológica INE-SEMARNAT, 62, 21-37.

Voss, R. S., Hubbard, C., \& Jansa, S. A. (2013). Phylogenetic Relationships of New World Porcupines (Rodentia, Erethizontidae): Implications for Taxonomy, Morphological Evolution, and Biogeography. American Museum Novitates, 3769, 1-36.

Wainwright, M. (2002). The Natural History of Costa Rican Mammals. Miami, Florida, USA: Zona Tropical S. A. Publisher.

Wilson, D. E. \& Reeder, D. A. M. (2005). Mammal species of the World. A taxonomic and geographic reference (Third edition). Baltimore, USA: The Johns Hopkins University Press. 